\title{
Investigating shoreline development along of Marsa Matrouh coastal zone area
}

\author{
Walid El Bably ${ }^{1}$, Mohamed Abdel Meguid ${ }^{1}$, Hany Mostafa ${ }^{1}$ and Mohamed F. M. Bakery ${ }^{2}$ \\ 1-Environment \& Climate changes Research Institute-Delta Barrages, P.O. Box 13621, Kalubyia, Egypt \\ 2- National Water Research Center, Fum Ismailia Canal, P.O. Box74, Cairo, Egypt.
}

\begin{abstract}
This study aimed to assess the possible utilization of rain-fed agriculture with minimum negative impacts on shoreline stability in the area $60 \mathrm{~km}$ east and west of the Marsa Matrouch City along the coastal zone of Egypt. To achieve this main goal, the soil characteristic and sediment transported by flash floods were collected for this area in addition to metrological data for 1961-1999 years. The study covered an area of $240 \mathrm{Km}^{2}$ including a 21 main wades and covered 2-4 year storm. Assessment of the sediment transport phenomena and accumulated sediment in the study area showed no relationship to the amount of precipitation and therefore did not cause any side effect on beaches and depressions considered for this study. In addition, the present study showed that the sediment transport did not have a great influence on the formation of the beaches even for wades with small cross section area. Accordingly, it was concluded that the water runoff from the small catchment areas can be harvested and used as potential source of water for the establishment of agricultural system based on irrigated lands or integrated rain-fed and irrigated systems.
\end{abstract}

Key words: Shoreline development, Marsa Matrouh, coastal zone.

\section{INTRODUCTION}

In the Northern part of Egypt the coastal line extends for about $550 \mathrm{~km}$ from Salum on the border of Libya to Abu Qir on the western fringe of the Nile Delta. This coast is characterized by a series of long limestone ridges running parallel to the sea, interspersed by depressions containing salt marshes. The relatively high precipitation (up to $200 \mathrm{~mm}$ per year) promotes rich vegetation growth. Livestock grazing and rain-fed agriculture in places constitute the main land-use.

In case of Matrouh Governorate, at the northern west of Egypt, its coastline is 500 $\mathrm{km}$ long with coastal area covers about $15000 \mathrm{~km}^{2}$. Within this area there are El Omayad Protectorate with an area of $700 \mathrm{~km}^{2}$, in addition to several other areas which have been surveyed and are being nominated as protected areas, including about $2500 \mathrm{~km}^{2}$ area between Matrouh and Salum. The coastal belt consists of a coastal plain and tableland. The coastal plain is fairly wide with calcareous sand dunes along the coast and series of long calcareous ridges running parallel to the sea with depressions containing salt marshes. The inland tableland is a relatively flat plateau containing rich steppe habitat. There are five main micro-habitats within the tableland which include the coastal sand dunes, the inland ridges, the saline depressions, non-saline depressions and the inland plateau (Abdel Meguid et al., 2006 a \& b).

The area has some of the highest annual rainfall in the country. The relatively high precipitation (up to $170 \mathrm{~mm}$ ) gives rise to a rich belt of vegetation along the coast, which becomes gradually sparser as one travels south turning into the hyper-arid terrain characteristic of the Western Desert. There are four agro-ecological zones from north to south - firstly, an agricultural belt in the coastal strip, where rainfall is highest, populations 
are settled and the area has good soils for irrigated fruit cultivation. Secondly, a mixed production strip ranging $5-15 \mathrm{~km}$ inland where the population is settled with a mixed sheep/goat herdingcum- barley farming system. Thirdly, a rangeland strip where the lack of water is limiting the livestock and agriculture activates and fourthly, a desert ecosystem with true nomads prevails. The coastal area under consideration is shared by 2 governorates, namely: Alexandria and Marrouh . However, the area of focus is Marsa Matrouh, which is the capital of Matrouh Governorate. It has a population of 50,000 capita and the total population of the area is estimated at 227,840 capita of which $85 \%$ are Bedouin. (EMA, 1996; Gamal and Kamel, 2000; EEAA, 2003; SPA, 2005; Abdel Meguid et al., 2006 a \& b).

Many studies were carried out by the Shore Protection Authority (SPA) and Governorate of Matrouh to attain practical solution for the problems facing Matrouh shorelines, which may diminish the preservation of investment and development opportunities at the Governorate. In such coastal area, the shoreline is subjected to many inputs and outputs that may dramatically affect the surface area, the length of the shoreline, and the depth of water in the coastal shallow water. The inputs include sand dunes, sand movement by waves, sediment transported by flash floods, organic material deposits, and wave's deposits at bays entrances. On the other hand, the outputs include the erosion of the beach and deposition at the shore. All these environmental variables are interacting to determine the degree of stability of the shoreline area.

With reference to reviewing the Shoreline Management Plan (SMP) and the preliminary environmental impact assessment for Matrouh Pilot Area located between 60 $\mathrm{km}$ east and $60 \mathrm{~km}$ west to Marsa Matrouh, no site-specific data on the development and/or shoreline stabilization are found to describe the characteristic of this area, e.g. high-risk erosion area, valuable sand source, ecologically significant habitat, moderately developed shorefront, highly developed shorefront and managing shoreline erosion impacts in the coastal environment; as well as water availability and sedimentation along the shoreline specially during an intensive rainfall storms that occur under certain meteorological conditions.

The present study aimed to assess the possible utilization of rain-fed agriculture with minimum negative impacts on shoreline stability in the area $60 \mathrm{~km}$ east and west of Marsa Matrouch City along the coastal zone of Egypt. Such assessment will give necessary information to increase the productivity of water, improve food security, and provide sustainable livelihoods through better development and management of the water, land, and agriculture to meet the demand of the growing area.

\section{1- The study area}

\section{MATERIALS AND METHODS}

The study area is a part of the Mediterranean coastal belt of Egypt. Its length is about $120 \mathrm{~km}$ long within locations setting between $27^{0} 38^{\prime} \mathrm{E}$ and $26^{0} 59^{\prime} \mathrm{E}$. Therefore, this area falls within the arid climatic province, which is characterized by hot, dry climate and rainless summer, and generally mild climate with little to moderate rainfall in winter. However, heavy rainfall storms may eventually happen during December and January. Its precipitation ranges between 25 and $30 \mathrm{~mm}$ with a duration period that ranges between 2436 hours. In the past, the annual rainy storm in the study area was recorded to be about four times a year, but, recently, it occurs two times. According to the Egyptian Metrological Authority, (EMA, 1996) regular monthly recorded of metrological parameters for the period 1961 to 1990 are shown in Table (1). The mean elevation of the study area varies 
from 65 to 128 meter above sea water level "according to the 1:10,000 maps (SPA, 2005). There are more than 18 villages, 132 Kafrs and 100 valleys (wades) located in this area (EEAA, 2008).

Table (1). Meteorological data of Marsa-Matrouh (1961 - 1990).

\begin{tabular}{|l|c|c|c|c|c|c|c|c|c|c|}
\hline \multirow{2}{*}{ Month } & \multicolumn{2}{|c|}{$\begin{array}{c}\text { Temperature } \\
\left({ }^{\mathbf{0}} \mathbf{C}\right)\end{array}$} & \multicolumn{2}{c|}{$\begin{array}{c}\text { Precipitation } \\
(\mathbf{m m})^{\mathbf{1}}\end{array}$} & \multicolumn{2}{c|}{ Sun shine } & \multicolumn{2}{c|}{$\begin{array}{c}\text { Humidity } \\
(\boldsymbol{\%})\end{array}$} & \multicolumn{2}{c|}{$\begin{array}{c}\text { Pressure } \\
(\text { hpa })\end{array}$} \\
\cline { 2 - 14 } & Max. & Min. & Max. & Min. & Max. & Min. & Max. & Min. & Max. & Min. \\
\hline January & 15 & 10 & 50 & 25 & 65 & 60 & 70 & 60 & 1020 & 1018 \\
\hline February & 15 & 10 & 25 & 15 & 70 & 65 & 70 & 60 & 1016 & 1014 \\
\hline Marsh & 15 & 10 & 25 & 15 & 70 & 65 & 70 & 60 & 1016 & 1014 \\
\hline April & 20 & 15 & 2 & - & 70 & 65 & 70 & 60 & 1016 & 1014 \\
\hline May & 20 & 15 & 2 & - & 80 & 75 & 70 & 60 & 1016 & 1014 \\
\hline June & 25 & 20 & 5 & 2 & 85 & 80 & 80 & 70 & 1016 & 1014 \\
\hline July & 25 & 20 & - & - & 90 & 85 & 80 & 70 & 1012 & 1010 \\
\hline August & 30 & 25 & - & - & 90 & 85 & 80 & 70 & 1012 & 1010 \\
\hline September & 25 & 20 & 5 & 2 & 85 & 80 & 70 & 60 & 1016 & 1014 \\
\hline October & 25 & 20 & 25 & 15 & 80 & 75 & 70 & 60 & 1018 & 1016 \\
\hline November & 20 & 15 & 25 & 15 & 75 & 70 & 70 & 60 & 1018 & 1016 \\
\hline December & 15 & 10 & 50 & 25 & 65 & 60 & 70 & 60 & 1020 & 1018 \\
\hline
\end{tabular}

1 average annual precipitation amount to $200 \mathrm{~mm}$.

The study area is differentiated into several geomorphic units (El-Deftar, 1976) as shown in Figure (1). These include:

1. Marmarica Plateau: This plateau covers the main surface of the North Western Desert. It forms the northern walls of the Qattara Depression. The plateau surface is usually covered by flat Miocene chalky limestone and hard limestone of Pliocene age. The surface of the plateau rises about $200 \mathrm{~m}$ above sea water level (a.s.w.l.) at the middle part and gradually loses its height to north where the elevation is about $20 \mathrm{~m}$ a.s.w.l. at the cliffs over looking the sea. The plateau is dissected by many wades mostly trending to north-south and south-north. The water dived lies at the middle of the plateau.

2. Scarp Face: The northern scarp fades gradually out to the east. It's altitude ranges from 50 to $100 \mathrm{~m}$ a.s.w.l. It has a very smooth outline, with minor wades crossing the face of the scarp, reaching the sea and forming the cliffs.

3. Coastal Plain: Near the Mediterranean Sea, the coastal plain stretches all over the study area between Fukha and Marsa Gargub west. Along this stretch $(120 \mathrm{~km})$, the plain is flat, slightly undulated and covered by beach sand and calcarnaite ridges known as kurkar. The average plain elevation is about $50 \mathrm{~m}$ that sloping towards the sea and over looks the Mediterranean Sea west Marsa Matrouh with near by vertical scarps. The 
elevation ranges between 30 and $100 \mathrm{~m}$ a.s.w.l. The coastal plain contains Mariout Depressions, White Oolitic Sandstone Ridges, Lake Deposits and Wadi Deposits. There are more than 100 wades within the northern part of Mamarica Plateau. They are covered by Fluvial deposits which are well cultivated by the local inhibitions.

4. Desert Soil: The plateau surface is mainly covered by desert soil and it is well cultivated by the inhibitions or local rainfall.

The land use in the study area is dominated by rain-fed cultivated area, followed by wetlands and depressions, grazing and sand dune areas, as well as some urban activities (Abdel Meguid et al., 2006 b).

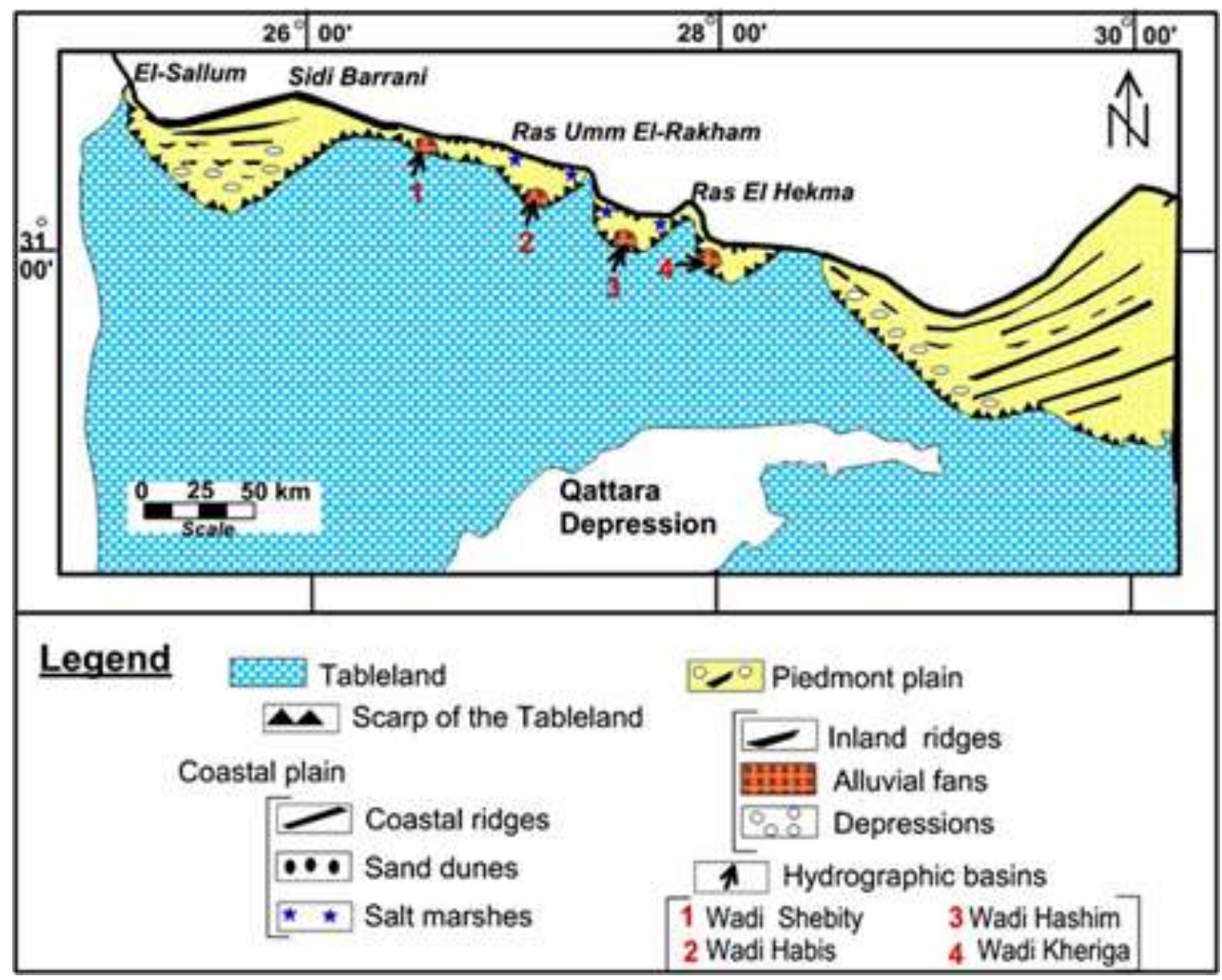

Fig. (1). Geomorphic units in the study area

\section{2- Identification of pilot area soil characteristics}

To study the characteristic of soil in the study area, 2 locations within 2 important wades (20 and 21) from 21 wades were determined (Fig. 1). The soil texture and its grain size were determined as well as its physicochemical parameters were analyzed using standard methods of APHA (1998).

\section{3- Calculation of the sediment transport}

In order to estimate sedimentation rate, the morphological characteristics of wades in the study area were determined. Also, the peak discharge or peak flash flood flow, design flows on small to medium urban coastal catchments were calculated and assessed using the rational method (Maidment, 1992; IEA, 2001), which is a simplistic equation for 
calculating peak flow using rainfall intensity, catchment area and a runoff coefficient for small catchments as the following formula: (Dunne and Leopold, 1978)

Where:

$$
\mathrm{q}=0.278 \text { c.I.A }
$$

$$
\begin{array}{ll}
\mathrm{q}=\text { peak flash flood flow } & \left(\mathrm{m}^{3} / \mathrm{s}\right) \\
\mathrm{c}=\text { runoff coefficient } & \\
\mathrm{I}=\text { average rainfall intensity } & (\mathrm{mm} / \mathrm{h}) \\
A=\text { catchment area }(\text { NZIE, 1980) } & \left(\mathrm{km}^{2}\right)
\end{array}
$$

This method is based on the assumption that a steady uniform rainfall rate in time and space will produce maximum runoff when all parts of the watershed are contributing to outflow. This condition is met when the storm duration exceeds the time of concentration. It is used to calculate the surface runoff discharges generated from a design storm with a specific return period and a duration time equal to the time of concentration of the catchments. This method translates the rainfall to runoff. (Maidment, 1992 and Nzie, 1980). The catchments area has been estimated by dividing the area on the map into sizes and numbers.

The time of concentration (tc) is the time at which the entire watershed begins to contribute to runoff; this is calculated as the time taken for runoff to flow from the most hydraulically remote point of the drainage area to the point under investigation. Using of the rational formula requires information about the time of concentration for each design point within the drainage basin. The duration of rainfall is then set equal to the time of concentration and is used to estimate the design average rainfall intensity (I).

Moreover, the sediment transport along different valley "wades" that have been selected was determined in the present study. The theory of Engelund and Hansen (1972) or calculating sediment transport was applied.

For the present investigated area, Chezy - Manning Friction Coefficient was used as Strickler's formula as shown in equation (2):

$$
C=M \cdot h^{1 / 6}
$$

Where:

$\mathrm{C}=$ Chezy coefficient

$M=1 / \mathrm{n}$ : Manning friction coefficient ( $\mathrm{M}$ is assumed to be 40 )

$\mathrm{h}=$ water depth (assumed to be $1 \mathrm{~m}$ )

Shear velocity can be calculated as follows:

$$
\mathrm{U}_{\mathrm{f}}=\frac{\sqrt{g}}{C} V
$$

Where:

$$
\begin{array}{ll}
\mathrm{U}_{\mathrm{f}}=\text { Shear velocity } & (\mathrm{m} / \mathrm{s}) \\
\mathrm{g}=\text { gravitational acceleration } & \left(\mathrm{m} / \mathrm{s}^{2}\right) \\
\mathrm{C}=\text { chezy coefficient } & \\
\mathrm{V}=\text { mean current velocity } & (\mathrm{m} / \mathrm{s})
\end{array}
$$

The dimensionless bed shear stress is defined as:

$$
\theta=\frac{U_{f}^{2}}{(S-1) g . d}
$$


Where:
$\theta=$ bed shear stress
(dimensionless)
$\mathrm{U}_{\mathrm{f}}=$ Shear velocity
$(\mathrm{m} / \mathrm{s})$
$\mathrm{S}=$ relative density of the bed material
(assumed to be 2.65)
$\mathrm{d}=$ grain size diameter $\left(\mathrm{d}_{50}\right)$

The dimensionless rate of total load transport $\Phi_{t}$, is defined as:

$$
\Phi_{t}=0.1 \frac{C^{2}}{2 \cdot g} \cdot \theta^{2.5}
$$

Where:
$\theta=$ bed shear stress
$\mathrm{g}=$ gravitational acceleration
(dimensionless)
$\mathrm{C}=$ chezy coefficient
$\left(\mathrm{m} / \mathrm{s}^{2}\right)$

The dimensionless total load transport $\mathrm{Q}_{\mathrm{t}}$, is defined as:

$$
\mathrm{Q}_{\mathrm{t}}=\Phi_{t} * \sqrt{(S-1) g d^{3}}
$$

Where:

$\mathrm{Q}_{\mathrm{t}}=$ sediment transport $/ \mathrm{m}$

$\mathrm{d}=$ grain size diameter

$\mathrm{S}=$ relative density of the bed material $\quad$ (assumed to be 2.65)

\section{RESULTS AND DISCUSSION}

It was rather difficult to investigate all the wades in the area in detail. So the present study selected 21 important wades based on their sizes and catchment area. By using the topographic maps of scale 1:10,000, the locations and main morphological data for each wadi are presented in Table (2) and Figure (2). The longest wadi was Wadi El-Hash (49.1 $\mathrm{km}$ ) followed by Wadi El-Agromia $(34.3 \mathrm{~km})$. Also, it is clear from the present study that Wadi El-Agromia had the biggest catchments area $\left(151.3 \mathrm{Km}^{2}\right)$ followed by Wadi El-Hash with an area of $103 \mathrm{Km}^{2}$. The main characteristics of each wadi locating in the study area could be summarized as the following:

1. The basin has a fairly narrow width and relatively long main course.

2. It has ephemeral valley.

3. It has vast extension of inter-basins.

4. It has very irregular recharge with considerable variation in the quantity and the quality of water supply.

This could reflect a high order of variability in space and time of individual storms, seasonal and total annual rainfall. The rate of water movement subjected to rainfall was based on the slope of the main branches in each sub basin. The average slope for each sub basin of the main stream varied considerably from one sub basin to another. It ranged between $8 \mathrm{~m} / \mathrm{km}$ and $12 \mathrm{~m} / \mathrm{km}$. Therefore the soil cover has made most of the slopes unstable which may be subjected to intensive erosion caused by storms.

Based on the present study the surface runoff was found ranging between 13.6 and 1512 $\mathrm{m}^{3} / \mathrm{s}$. The lowest surface runoff was located in Wadi El-Garnok while the highest one was located in Wadi El-Agromia. Also the present study showed that the stream density within the wades was ranging between 0.21 and 1.38 . The highest value tends to give more chance for collection the surface runoff. 
As far as the drainage densities are concerned, the calculated values were found to range from as low as between $0.22 \mathrm{~km}^{-1}$ (Wadi El-Agromia) to as high as $1.21 \mathrm{~km}^{-1}$ (Wadi Tahia). The lowest drainage density value is due to the presence of small length of segments which is characterized by high permeability with flat area covered with dense plant vegetation. This feature alone is in favour in diminishing the run-off risk, besides it encourages rapid percolation of rainfall. While the highest drainage density value is related to the presence of large length of the tributaries which is characterized by low permeability with steep surface area covered with less density of plant vegetation. In general, these values are classified as extremely low indicating meanwhile that the basin subsoil is highly permeable.

On the other hand, the present study showed that the value of the length of overland flow ranged between 0.25 and 2.27. Such parameter may act as an important indicator for the drainage texture.

Concerning the shape of the catchments and its sub-basins, it is considered as an important factor in determining runoff pattern of the stream. The shape of the catchments is defined by the ratio assigned by elongation ratio (Er) which is defined as the ratio of the diameter of a circle of the same area as the basin to the maximum basin length. The ratio approaches one as the shape of the catchments approaches a circle. The present study showed that the elongation ratio ranged between 0.064 and 1 . In general, the highest value is the greatest.

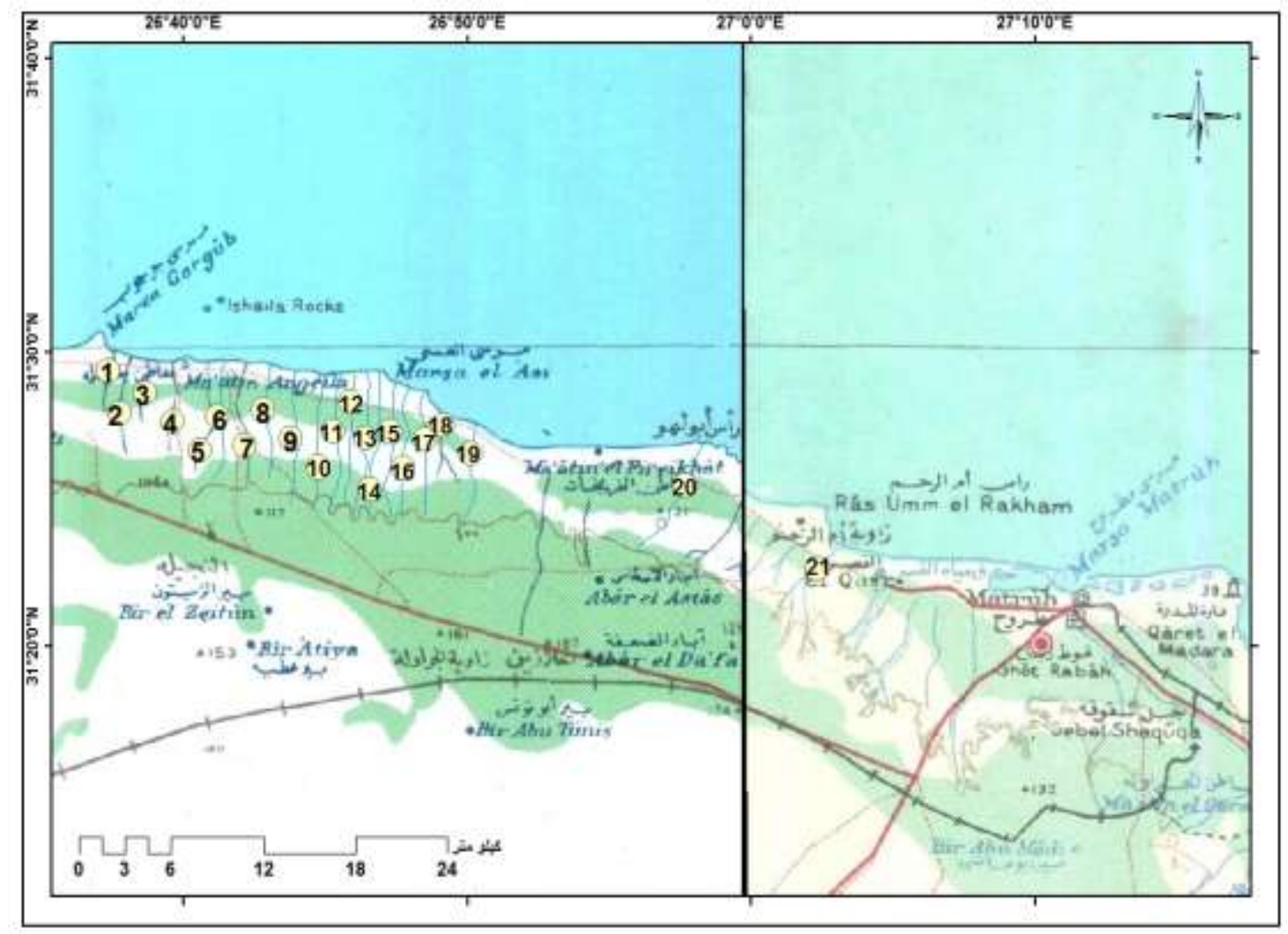

Fig. (2). Morphological parameters of different wades within the study area (1-21 wades).

The Bifurcation ratio $(\mathrm{Rb})$ is used to indicate the shape of the catchments. Generally, this ratio is inversely proportional to flood discharge. The present study showed that the bifurcation ratios in the various wades varied between 0.25 and 1.0. As shown in 
Table (2), Wadi Hagaria had the lowest ratio which indicated that the discharge were high with sharp peaks. While wades Abu Hisha, El-Hawia, El-shibity, El-Zohairy, Abu Safa, Malah, Senab and Tahia had the highest ratio which indicated that the discharge was low with extended peaks. In this regard, the wades in the study area which has a low bifurcation ratio is fortunately of small areal extent and therefore its eventual risk is greatly diminished.

The slope is also considered as another parameter which can be used to indicate the difference between the highest and lowest latitude of the wadi. It may act as an important indicator for erasing. The present study showed that the slope ranged between 8 and 12 $\mathrm{m} / \mathrm{km}$. Moreover, the present study showed that the study area is flat and covered by Miocene and Pliocene limestone (Marmarica Plateau). It is gently inclined towards the north, Approaching the Mediterranean Sea, Quaternary silt, sands and calcalnite are very common.

Marmarica Plateau dissected by many wades, are inclined toward the Mediterranean Sea with a gradient range between $8 \mathrm{~m} / \mathrm{km}$ to $12 \mathrm{~m} / \mathrm{km}$. The catchments area of these valleys (wades) is ranging between 1.36 to $151 \mathrm{~km}^{2}$. The Marmarica plateau receives seasonally rainfall ranging between 100 to $200 \mathrm{~mm} /$ year. Due to the water rainfall, several flash floods are flowing and carrying detritus materials from the catchments area. Those materials consist of gravels, grits, coarse and fine sands, silt and clay. Most of these loads go finally to the Mediterranean Sea.

Table (2). Summery of morphological parameters of different wades.

\begin{tabular}{|c|c|c|c|c|c|c|c|c|c|c|c|c|c|c|c|c|c|c|c|c|c|}
\hline Wadi & 1 & 2 & 3 & 4 & 5 & 6 & 7 & 8 & 9 & 10 & $\mathrm{n}$ & 12 & 13 & 14 & 15 & 16 & 17 & 18 & 19 & 20 & 21 \\
\hline $\begin{array}{l}\text { No. } \\
\text { Aspect }\end{array}$ & 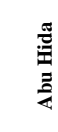 & 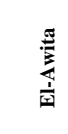 & 弟 & 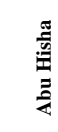 & 音 & $\begin{array}{l}\frac{\pi}{\pi} \\
\frac{\pi}{1} \\
\frac{1}{x}\end{array}$ & 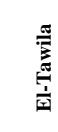 & 童 & 党 & $\frac{\stackrel{3}{\pi}}{\frac{1}{0}}$ & 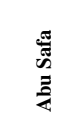 & 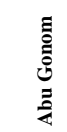 & $\frac{\overline{\text { J }}}{\bar{N}}$ & $\frac{\frac{\pi}{\sigma}}{\frac{\sigma}{\sigma}}$ & 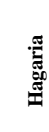 & 馬 & $\begin{array}{l}\text { है } \\
\text { ผूँ }\end{array}$ & 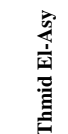 & 䍃 & $\begin{array}{l}\frac{5}{5} \\
\frac{\pi}{1} \\
\frac{1}{\Gamma x}\end{array}$ & 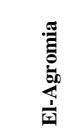 \\
\hline $\begin{array}{c}\text { Length } \\
(\mathbf{K m})\end{array}$ & 23 & 23 & 2.5 & 23.6 & 14.1 & 23 & 24.5 & 24.5 & 25 & 4.5 & 11 & 13.5 & 23 & 21 & 22 & 23.7 & 26.3 & 23.3 & 4.3 & 49.10 & 34.26 \\
\hline $\begin{array}{l}\text { Catchments } \\
\text { Area }\left(\mathbf{k m}^{2}\right)\end{array}$ & 22.11 & 37.96 & 1.36 & 30.17 & 53.36 & 30 & 34.60 & 20.4 & 51.42 & 3.19 & 10.21 & 15.04 & 17.7 & 16.23 & 29.7 & 28.52 & 54.35 & 27.77 & 3.56 & 102.97 & 151.24 \\
\hline $\begin{array}{c}\text { Slope } \\
(\mathbf{m} / \mathbf{k m})\end{array}$ & 8 & 11 & 12 & 12 & 9 & 9 & 10 & 10 & 11 & 12 & 12 & 12 & 10 & 11 & 10 & 10 & 10 & 11 & 11 & 12 & 12 \\
\hline $\begin{array}{c}\text { Surface } \\
\text { Runoff } \\
\left(\mathbf{m}^{3} / \mathbf{S}\right) \\
\end{array}$ & 221.1 & 379.6 & 13.6 & 301.7 & 533.6 & 300 & 346 & 204 & 514.2 & 31.9 & 102.1 & 150.4 & 177 & 162.3 & 297 & 285.2 & 543.5 & 277.7 & 35.6 & 1029.7 & 1512.4 \\
\hline $\begin{array}{c}\text { Bifurcation } \\
\text { Ratio }\end{array}$ & 0.5 & 0.66 & 0.6 & 1 & 1 & 0.4 & 0.67 & 1 & 0.8 & 1 & 1 & 0.75 & 0.33 & 1 & 0.25 & 0.33 & 1 & 0.8 & 1 & 0.385 & 0.375 \\
\hline $\begin{array}{c}\text { Stream } \\
\text { density } \\
(\mathrm{N} / \mathrm{A})\end{array}$ & 1.04 & 0.601 & 1.8 & 0.78 & 0.26 & 0.7 & 0.7 & 1.2 & 0.482 & 1.4 & 1 & 0.89 & 1.3 & 1.2 & 0.71 & 0.83 & 0.48 & 0.84 & 1.2 & 0.21 & 0.138 \\
\hline $\begin{array}{c}\text { Drainage } \\
\text { density } \\
\text { (L/A) }\end{array}$ & 1.04 & 0.61 & 1.84 & 0.78 & 0.264 & 0.76 & 0.71 & 0.71 & 0.48 & 1.41 & 1.07 & 0.89 & 1.29 & 1.29 & 0.74 & 0.83 & 0.48 & 0.84 & 1.21 & 0.47 & 0.22 \\
\hline $\begin{array}{l}\text { Range in } \\
\text { Elevation } \\
\text { (m) a.s.w.l }\end{array}$ & 80 & 90 & 72 & 75 & 106 & 79 & 10.5 & 75 & 10.6 & 60 & 65 & 75 & 78 & 80 & 103 & 105 & 108 & 110 & 110 & 127 & 128 \\
\hline $\begin{array}{c}\text { Elongation } \\
\text { Ratio }\end{array}$ & 0.95 & 1.02 & 0.4 & 0.4 & 1 & 1 & 1 & 0.94 & 1 & 0.8 & 0.7 & 0.65 & 0.5 & $\begin{array}{l}0.9 \\
\end{array}$ & 1 & 1 & 1 & 1 & 1 & 0.067 & 0.146 \\
\hline $\begin{array}{c}\text { Length of } \\
\text { overland }\end{array}$ & 0.48 & 0.51 & 0.25 & 0.23 & 1.05 & 0.65 & 1 & 0.47 & 0.55 & 0.42 & 0.35 & 0.34 & 0.25 & 0.4 & 0.6 & 0.85 & 0.53 & 0.925 & 0.6 & 1.06 & 2.27 \\
\hline $\begin{array}{c}\text { Ordered } \\
\text { No. }\end{array}$ & 2 & 3 & 1 & 3 & 2 & 2 & 4 & 4 & 4 & 3 & 3 & 3 & 2 & 2 & 3 & 7 & 4 & 4 & 4 & 5 & 4 \\
\hline
\end{tabular}


Inland, the low areas near the shore are covered by carbonate washed material from the surrounding limestone ridges and also by clays transported into these depressions by floods. The resulting fertilized soil is formed and cultivated by the local inhabitants.

The coastal plain in the investigated area is a narrow strip. Its width is ranging between 300 to $500 \mathrm{~m}$. The Miocene scarp limestone lies directly overhang the water. In the last decade, many artificial constructions established near the outlets of the wades, prevented the detritus material carried by the flood to precipitate inside the sea for protecting shoreline and rebuild white snow sand dunes. That is why the sediments carried by floods, is considered as one of the most important elements to stabilize the shoreline.

The mouth of the wades are very thin and is not clear enough at the given satellite images. Therefore, it is very difficult to calculate the cross section area from the satellite image or even by using, the scale of 1:10000 maps which may show high error.

To avoid this error during calculating of the sediment accumulation within 21 wades locating in the study area, seven scenarios were applied. Those scenarios were based on the assumption that the rainfall intensity $(5-50 \mathrm{~mm})$. Table (3) illustrates the amount of sediment accumulation within the selected 21 wades for each scenario. The study showed that the sediment transport was the highest in Wadi El-Agromia followed by Wadi El-Hash. The cross section area was estimated to be in the range of 5 and $50 \mathrm{~m}^{2}$, the sediment accumulation was ranged between $1.5 \mathrm{E}+08$ and $14964.9 \mathrm{~m}^{3}$ in Wadi ElAgromia and 2.2E+07 and $2189.24 \mathrm{~m}^{3}$ in Wadi El-Hash. Based on the seven scenarios, the present result showed that the sediment accumulations within the rest 19 wades were very low when they compared with Wadi El-Agroma. Moreover, it is concluded from Table (3) that even though the use of the seven Scenarioss (based on the assumption that the rainfall intensity $5-50 \mathrm{~mm}$ ) to estimate the rate of sedimentation within 21 wades, the present result showed that the amount of precipitation does not cause any side effect on the beaches or depressions that locating in the study area. Also it is considered that the sediment transport does not represent a great importance in the formation of the beach within the study area even in the presence of small cross section area.

For water management, the non saline depressions which are located in the study area can be used as water harvesting. In such depressions, water storage structures (reservoirs) can be constructed in order to harvest rain water for household use, animal watering and limited supplemental irrigation. Those reservoirs can be mainly constructed in the depressions to collect and store water that are coming from the floods to be used for fish production and agriculture. This strategy will offer the potentiality to increase food security, enhance agricultural productivity and improve livelihoods.

Based on previous study (Abdel Meguid, et al., 2006 b), there are rain-fed agriculture land in the study area, its area is about 4552 hectares. Also, this previous study showed that the estimated area of irrigated land is about 2084 hectares. These irrigated lands are found in scattered ways near the wadi beds and non-saline inter-ridge depressions that receive water flooding and near the coastal sand dune that receive ground water (wells and springs). To study the suitability of such land for agriculture, the soil characteristics were identified in the present study because it is important to have good knowledge of soil characteristics, their distribution as well as of the existing fresh water (Hamdi (2001).

Previous study showed that the soils in the costal area are sandy loam to sandy clay loam (Ghabbour, 2012). Similarly, the present study showed that the soil texture tended to be sandy where the percentage of silt raged between 2 and $13 \%$ and the clay 
ranged between 3 and $5 \%$, while the dominant sand ranged between 82 and $95 \%$ as shown in Table (4). Also the present study showed that the dominated grain size ranged between 0.1 and $0.25 \mathrm{~mm}$ (Table 5). The organic carbon content of the surface soil is Zero. Also, the current study indicated that the values of $\mathrm{pH}$ within surface soil ranged between 8.2 and 8.5 (Table 6). The electrical conductivity of the soil can act as indicator of the total dissolved inorganic salts and other solids (Moore and Moore, 1976). The current study showed that the electrical conductivity of the soil within the study area was low which is coincide with finding of Ghabbour (2012) who indicated that soil are characterized by low salt content. It ranged between 1.7 and $15.4 \mathrm{mmhos} / \mathrm{cm}$ (Table 6). Concerning the anion and cations, the present result showed that the most predominant anions and cations were sulfate and calcium respectively. The saline and sodic soils develop in this region where the precipitation is very limited with poor drainage. Under such conditions evaporation and evapotranspiration are not compensated by precipitation and irrigation. Salts, weathered from rocks and minerals, deposited by rainfall and wind, are insufficiently washed from the upper soil layers. With evaporation these accumulated salts precipitate from upward-moving water on or near the surface. Excessive salts hinder crop growth by toxic effects, reduce water availability through the action of osmotic pressure, and may result in unbalanced nutrient uptake. To reduce the negative effects of salinity, irrigation techniques and gypsum (CaSO4) application or by growing salttolerant crops such as (field crops- Barley, Cotton), (fruit crops- Date Palm, Olive, Fig) and (vegetable crops- Tomato, Cucumber, Potato) should be implemented in the sandy soil.

It was clear that heavy metals accumulate in the soil through complex physical and chemical adsorption mechanisms depending on the nature of the soil matrix and the properties of the adsorbed compounds (Maher and Aislabie, 1992). Several processes lead to the association of heavy metals with solid phases, such as the direct absorption by fine-grained inorganic particles of clays; adsorption of hydrous ferric and manganic oxides which may in turn be associated with clays; adsorption on or complexation with natural organic substances, which may also be associated with inorganic particles, and direct precipitation as new solid phases (Gibbs, 1973). The adsorption process is influenced by several chemical-physical and chemical parameters such as: $\mathrm{pH}$, oxidative-reductive potential, dissolved oxygen, organic and inorganic carbon content, and the presence in water phase of some anions and cations that can bind or coprecipitate the water-dissolved or suspended pollutants (Wen and Allen, 1999). The present study showed that all parameters fractions of the trace metals were below the permissible level according to the Canadian Law. These essential elements are naturally derived from weathering of rocks and minerals; and most of the crops require such small concentrations that they are called micronutrients for their growth.

So, from the above statements, it is necessary to modify the existing management practices in the study area by adopting new technology for water harvesting. Such modifications must occur at both the small scale of individual and properties as well as the broad scale to improve crop/water productivity in the study area. 
Table (3). Sediment transportation in cubic meter of different wades for each cross section area.

\begin{tabular}{|c|c|c|c|c|c|c|c|c|}
\hline \multicolumn{2}{|c|}{ Scenarios } & 1 & 2 & 3 & 4 & 5 & 6 & 7 \\
\hline \multicolumn{2}{|c|}{$\mathrm{A} 1\left(\mathrm{~m}^{2}\right)$} & 5 & 10 & 15 & 20 & 30 & 40 & 50 \\
\hline \multicolumn{9}{|c|}{ Wadi } \\
\hline 1 & Abu Hida & 9992.7 & 624.55 & 123.37 & 39.034 & 7.7104 & 2.4396 & 0.9993 \\
\hline 2 & El-Awita & 149064 & 9316.47 & 1840.29 & 582.28 & 115.018 & 36.3925 & 14.9064 \\
\hline 3 & El-Garnok & 2919.3 & 182.5 & 36.04 & 11.40 & 2.252 & 0.712 & 0.291 \\
\hline 4 & Abu Hisha & 47273.4 & 2954.59 & 583.623 & 184.662 & 36.4764 & 11.5414 & 4.72734 \\
\hline 5 & El-Hawia & 818125 & 51133 & 10100 & 3195.8 & 631.27 & 199.74 & 81.812 \\
\hline 6 & El-Korat & 45956.5 & 2872.28 & 567.364 & 179.518 & 35.4603 & 11.2198 & 4.59565 \\
\hline 7 & El-Tawila & 93782.3 & 5861.4 & 1157.81 & 366.337 & 72.3629 & 22.8961 & 9.37823 \\
\hline 8 & El-shibity & 6681.77 & 417.611 & 82.491 & 26.1007 & 5.15569 & 1.63129 & 0.66818 \\
\hline 9 & Insily & 679831 & 42489.4 & 8392.97 & 2655.59 & 524.561 & 165.974 & 67.9831 \\
\hline 10 & El-Zohairy & 0.62473 & 0.03904 & 0.00771 & 0.00244 & 0.00048 & 0.00015 & $6.25 \mathrm{E}-05$ \\
\hline 11 & Abu Safa & 209.83 & 13.114 & 2.5905 & 0.8196 & 0.1619 & 0.0512 & 0.0209 \\
\hline 12 & $\begin{array}{l}\text { Abu } \\
\text { Gonom }\end{array}$ & 1455.4 & 90.961 & 17.967 & 5.6851 & 1.1229 & 0.3553 & 0.1455 \\
\hline 13 & Wakal & 3285.5 & 205.34 & 40.562 & 12.834 & 2.5351 & 0.8021 & 0.3285 \\
\hline 14 & Malah & 2129.77 & 133.111 & 26.2935 & 8.31942 & 1.64334 & 0.51996 & 0.21298 \\
\hline 15 & Hagaria & 43704 & 2731.5 & 539.56 & 170.72 & 33.722 & 10.67 & 4.3704 \\
\hline 16 & Zeinab & 35685.2 & 2230.33 & 440.558 & 139.395 & 27.5349 & 8.71221 & 3.56852 \\
\hline 17 & Senab & 896888 & 56055.5 & 11072.7 & 3503.47 & 692.043 & 218.967 & 89.6888 \\
\hline 18 & $\begin{array}{l}\text { Thmid El- } \\
\text { Asy }\end{array}$ & 31233 & 1952.1 & 385.6 & 122.01 & 24.1 & 7.6254 & 3.1233 \\
\hline 19 & Tahia & 1.081 & 0.067 & 0.013 & 0.004 & 0.000 & 0.000 & 0.000 \\
\hline 20 & El-Hash & $2.2 \mathrm{E}+07$ & 1368277 & 270277 & 85517.3 & 16892.3 & 5344.83 & 2189.24 \\
\hline 21 & El-Agromia & $1.5 \mathrm{E}+08$ & 9353064 & 1847519 & 584566.5 & 115469.9 & 36535.41 & 14964.9 \\
\hline
\end{tabular}

Table (4). Soil texture at different locations.

\begin{tabular}{|c||c|c|c|c|}
\hline \hline Location No. & Texture & \% sand & \% silt & \% clay \\
\hline$(\mathbf{2 0})$ & Sandy & 82 & 13 & 5 \\
\hline$(21)$ & Sandy & 95 & 2 & 3 \\
\hline
\end{tabular}

Table (5). Grain size at different locations

\begin{tabular}{||c|c|c|c|c|c|c|c|c||}
\hline $\begin{array}{c}\text { Location } \\
\text { No. }\end{array}$ & $\begin{array}{c}\mathbf{0 . 0 6} \\
\mathbf{M m}\end{array}$ & $\begin{array}{c}\mathbf{0 . 1} \\
\mathbf{m m}\end{array}$ & $\begin{array}{c}\mathbf{0 . 2 5} \\
\mathbf{m m}\end{array}$ & $\begin{array}{c}\mathbf{0 . 3 1 5} \\
\mathbf{M m}\end{array}$ & $\begin{array}{c}\mathbf{0 . 4} \\
\mathbf{m m}\end{array}$ & $\begin{array}{c}\mathbf{0 . 6 8} \\
\mathbf{m m}\end{array}$ & $\begin{array}{c}\mathbf{0 . 8} \\
\mathbf{m m}\end{array}$ & $\begin{array}{c}\mathbf{1 . 6} \\
\mathbf{m m}\end{array}$ \\
\hline $\mathbf{( 2 0 )}$ & 9.4 & 26.0 & 25.8 & 7.4 & 7.0 & 4.1 & 7.4 & 5.8 \\
\hline $\mathbf{( 2 1 )}$ & 8.1 & 16.8 & 24.1 & 16.2 & 15.8 & 5.4 & 10.1 & 3.4 \\
\hline
\end{tabular}


Walid El Bably et al.

Table (6). Concentrations of physicochemical parameters in the soil at different locations.

\begin{tabular}{|c|c|c|}
\hline $\begin{array}{ll}\text { Location } & \\
\end{array}$ & 20 & 21 \\
\hline pH & 8.5 & 8.2 \\
\hline EC $(\mathbf{m m h o s} / \mathbf{c m})$ & 1.7 & 15.4 \\
\hline Calcium (mg/kg) & 65.7 & 60.4 \\
\hline Potassium $(\mathrm{mg} / \mathrm{kg}$ & 0.9 & 1.5 \\
\hline Magnesium (mg/kg) & 5.0 & 6.0 \\
\hline Sodium $(\mathrm{mg} / \mathrm{kg})$ & 2.6 & 3.2 \\
\hline Chloride (mg/kg) & $\mathbf{0}$ & $\mathbf{0}$ \\
\hline Nitrate (mg/kg) & 6.8 & 7.8 \\
\hline Phosphate (mg/kg) & 11 & 15 \\
\hline Sulfate $(\mathrm{mg} / \mathrm{kg})$ & 45.4 & 40.8 \\
\hline Copper $(\mathbf{m g} / \mathbf{k g})$ & 0.9 & 0.6 \\
\hline Lead $(\mathrm{mg} / \mathrm{kg}$ & 3.8 & 4.2 \\
\hline Nickel (mg/kg & 0.3 & 0.2 \\
\hline Iron $(\mathrm{mg} / \mathrm{kg})$ & 4.1 & 1.3 \\
\hline Zinc (mg/kg & 1.4 & 1.9 \\
\hline
\end{tabular}

\section{Conclusions}

The present study was carried out on a pilot scale in Matrouh Governorate, $60 \mathrm{~km}$ to the east and to the west to Marsa Matrouh city. The study aimed to assess the possible utilization of rain-fed agriculture with minimum negative impacts on shoreline stability in the studied area. Data collected and analyzed comprised metrological data for 12 months, soil characteristics and sediment transport. Results suggested that shoreline stability is independent of sediment transport and accumulation during a few flash floods. So, it is vital to harvest and store about $(80 \%)$ rainfall water that goes to the sea and flows down in the direction of the Mediterranean Sea.

Within this scope and parallel to the above conclusions sustainable development can be conducted in the study area to modify the existing the rain-fed practices by adopting new technology for supplementary annual irrigation for growing winter and summer crops. The potential water resources in the assessed area can be harvested from small catchment areas (around $40 \mathrm{MCM}$ per year) and can be sustainably utilized for agriculture purposes which may cover an area of about 2600 feddans to support poor rural village communities and supply urban areas with the needed quantity and variety of food.

\section{Recommendation}

More technical information is still needed about the development and/or shoreline stabilization for implementing the future status of land use, planning policy and development of the adjacent areas/regions such as El-Dabaa, Sidi Barrani, Fuka and ElSalloum.

\section{Acknowledgements}

The initiation of this work would not have been possible without the commitment, interest and co-operation of Dr. Jan Dietrich (NIRAS, Consulting Engineering and Planner, Denmark). So, it is our pleasant duty to express sincere appreciation to him for his insight and advice. 


\section{REFERENCES}

Abdel-Meguid, M.; Laila Abed; Jan Dietrich and Maha, M. Ali (2006 a). Water availability and vegetations along the coastal dune area in Marsa Matrouh. $3^{\text {rd }}$ Arab Water Regional Conference. Research Advancement in Managing Limited Water Resources. Cairo, Egypt.

Abdel-Meguid, M.; Mohamed Abdou; Hany, M. Ayad and Jan Dietrich (2006 b). A remote sensing approach for detecting land use/land cover on the coastal project management area of Marsa Matrouh. $3^{\text {rd }}$ Arab Water Regional Conference. Research Advancement in Managing Limited Water Resources. Cairo, Egypt.

APHAA (merican Public Health Association) (1998). Standard Methods of Examinations of Water and Wastewater. $20^{\text {th }}$ Edition, Washington, D.C.

Dunne, T. and Leopold, L.B. (1978). Water in Environmental Planning. W.H. Freeman \& Co. New York.

EEAA (Egyptian Environment Affair Agency) (2008). Environmental characterization for Matrouh Governorate.

EEAA (Egyptian Environment Affair Agency) (2003). Wetland Projects and Coastal Region in the Mediterranean Sea, Omaid Protectorate.

EMA (Egyptian Meteorological Authority) (1996). Climatic Atlas of Egypt.

SPA (Egyptian Shore Protection Authority) (2005). Shoreline Management Planning Along the Egyptian North West Coast of the Mediterranean Sea from ElDekhila to El-Salloum.

ESA (Egyptian Survey Authority) (1938). Marsa Matrouh Map, 1:100,000, (T/37/13).

ESA (Egyptian Survey Authority) (1994). Ras El- Hekma Map, 1:100,000, (37/94/5).

Engelund, F. and Hansen, E. (1972). A Monograph on sediment transport in Alluvial Streams. Teknish Forlag, Copenhagen.

El-Deftar, T. (1976). Explanatory Booklet of sheet El Baradia, 1:250,000 Tripoli, Libya.

Hamdi, A.S. (2001). Agriculture and soil survey in Egypt. In : Zdruli, P. ( ed.), Steduto P. ( ed.) , Lacirignola, C. ( ed.), Montanarella L. ( ed.). Soil ressources of Southern and Eastern Méditerranéen countries Bari : CIHEAM Options Méditerranéennes : Série B. Etudes et Recherches; n. 34 pages 111- 125.

Gamal, M. F. and Kamel, M. A. (2000.) Socio-Economic considerations affecting sustainable development in the Northern coast region of Egypt. International Conf. on Wadi Hydrology, Sharm El-Sheikh, Egypt, 21-23 November.

Ghabbour , S. I. (2012). Potential Impacts of Climate Change on Soil Fauna: Case of the

Xero-Mediterranean Omayed Biosphere Reserve (OBR), Egypt. Intern. J Environ. Sci. and Engin. (IJESE), (3): 71-83.

Gibbs, R.J. (1973). Water chemistry of the Amazon River. Geochim. Cosmochim. Acta 36:1006-1066.

IEA (Institute of Engineers Australia) (2001). Australian Rainfall and Runoff. A Guide to Flood Estimation. D.H. Pilgrim (Editor), Institute of Engineers Australia publication.

Maidment, D. (1992). Handbook of Hydrology. University of Texas, McGraw Hill, New York.

Maher, W.A. and Aislabie, J. (1992). Polycyclic aromatic hydrocarbons in nearshore marine sediments of Australia. Sci. Total Environ., 11 (2-3):143-164.

Moore, W.J. and Moore, E.A. (1976). Environmental Chemistry. Academic Press Inc., London

NZIE (New Zealand Institute of Engineers) (1980). A guideline and procedure for hydrological design of urban storm water systems. NZIE, Auckland, NZ. 


\section{Walid El Bably et al.}

Wen, X. and Allen, H.E. (1999). Mobilization of heavy metals from Le An River sediments. Sci. Total Environ., 227:101-108. 
135

Investigating shoreline development along of Marsa Matrouh coastal zone area 